\title{
A Collaborative Journey Toward Understanding the Role of Social Class in Teaching and Learning
}

\author{
Lynda R. Wiest ${ }^{1}$, Cynthia H. Brock ${ }^{2}$, Constance M. Morton ${ }^{3}$, Monica N. Colbert ${ }^{4}$, Ryan J. Linton ${ }^{5} \&$ Brittany \\ Herrera $^{6}$ \\ ${ }^{1}$ Professor, College of Education, University of Nevada, Reno, USA \\ ${ }^{2}$ School of Teacher Education, University of Wyoming, Laramie, Wyoming, USA \\ ${ }^{3}$ Grand Canyon University, Phoenix, Arizona, USA \\ ${ }^{4}$ Montgomery County Public Schools, Rockville, Maryland, USA \\ ${ }^{5}$ Washoe County School District, Reno, Nevada, USA \\ ${ }^{6}$ California State University, Dominguez Hills, Carson, California, USA \\ Correspondence: Lynda R Wiest, College of Education/299, University of Nevada, Reno, 1664 N. Virginia St., \\ Reno, NV, USA 89557. E-mail: wiest@unr.edu
}

Received: November 12, 2018 Accepted: December 10, $2018 \quad$ Online Published: December 30, 2018

doi:10.5539/jel.v8n1p1 URL: https://doi.org/10.5539/jel.v8n1p1

\begin{abstract}
One important area of development for educators at all levels is teaching students from diverse backgrounds, which includes attention to the important role of social class. In this reflective essay, two teacher educators and four students (two graduate, two undergraduate) examine the aspects of a course on social class and schooling that they perceive to have influenced favorable change in their learning and practice. Individual writings by the six participants at three checkpoints during and after the course generated four themes that the authors discuss in relation to the course content and pedagogy: salient content; effective instructional approaches; application of course material; and suggested improvements. Factors that contributed to course effectiveness included a focus on deep growth involving knowledge and dispositions; instructional methods that encouraged meaningful participant engagement and reflection in a "safe" classroom environment; and practical applications for course material. Suggested improvements centered on including direct engagement experiences and exploring individual course topics in greater depth.
\end{abstract}

Keywords: diversity, social class, teacher education, educational development, faculty development

\section{Introduction}

\subsection{The Relationship of Social Class to Education}

Social class can relate to education in important ways throughout schooling. This association is evident from the pre-kindergarten years in which educators have been shown to subtly guide students from higher-income families toward more academic play that promotes school readiness more so than for students from lower-income backgrounds (Stirrup, Evans, \& Davies, 2017) to the college years where students from lower-income backgrounds take significantly longer than their counterparts to complete an undergraduate degree (Zarifa, Kim, Seward, \& Walters, 2018). Research with students age 14 in England shows that students from lower-income families take less rigorous coursework in school (Henderson, Sullivan, Anders, \& Moulton, 2018). In summarizing 20 years of research in the United States, Hunt and Seiver (2018) identified a class-biased curriculum that tends to be skills-based and unfamiliar to students from lower-income families.

As a result of school-based inequities for students from different social-class backgrounds, students from low-income families show weaker self-efficacy, lower school performance, and higher school drop-out rates than students from higher-income families, and the achievement gap between students from lower- and higher-income families has widened in recent decades (Mahuteau \& Mavromaras, 2014; Reardon, 2011; Wiederkehr, Darnon, Chazal, Guimond, \& Martinot, 2015). For example, FairTest $(2013,2015)$ data show that U.S. students from a family income level of $\$ 20,000$ or less averaged 455 on recent SAT mathematics scores and students from a family income level of more than $\$ 200,000$ averaged 587 . Moreover, the scores went down 
slightly for students from lower-income families and up slightly for students from higher-income families from 2013 to 2015. Internationally, other standardized tests show similar evidence of a positive correlation between socioeconomic status (SES) and school performance (e.g., OECD, 2018).

According to Reardon (2011), "Family income is now nearly as strong as parental education in predicting children's achievement" (p. 93). Reardon notes that higher-income families possess more material and social resources than lower-income families, and they increasingly invest these resources, as well as their time, in their children's cognitive development. More affluent families have also been shown to hold higher expectations for their children to earn a college degree (Stull, 2013). When lower-income students do attend college, they report lower levels of satisfaction with the experience due to minimal participation in social and recreational activities because they often have to work part-time (Martin, 2012).

\subsection{Educator Preparedness to Teach Diverse Learners}

Preservice and practicing teachers tend to have weak knowledge, dispositions, and practices in relation to working with diverse learners, which can negatively influence their self-efficacy and classroom effectiveness (DeVillar \& Jiang, 2012; Kumar \& Hamer, 2012; Murdock \& Hamel, 2016; Robinson, 2017; Sharma et al., 2016). Based on their study with 784 preservice teachers, Kumar and Hamer (2012) report, "More than 25\% of preservice teachers in this study explicitly endorse stereotypic beliefs about poor and minority students. At a time when schools are becoming increasingly diverse, a high percentage of prospective teachers reported feeling uncomfortable with student diversity" (p. 173). In another study, preservice teachers demonstrated a disconnect between their reported beliefs and their perspectives on actual classroom practice, and they expressed fear about diversity-oriented teaching (Murdock \& Hamel, 2016). Practicing teachers have been found to make class-based assumptions that can influence their practice to the detriment of students from lower-income backgrounds. For example, they might perceive these students as having lower ability, interpret assessments of their work accordingly, and interact with and teach them differently (Hunt \& Seiver, 2018; Stirrup, Evans, \& Davies, 2017).

Educators tend to be insufficiently prepared to work with diverse learners. For one thing, they tend to have a limited conception of the meaning of diversity, often equating it mainly with race and ethnicity (e.g., Sharma et al., 2016). This constrictive view of diversity means that social class is not adequately addressed in the field of education (e.g., Stirrup et al., 2017). Indeed, a study of teacher educators, the very individuals who prepare P-12 teachers, reported not feeling comfortable or equipped to teach about social class (Jett \& Cross, 2016). Thus, the need for greater preparation for educators on teaching diverse students has been expressed for core curricular areas and co-curricular subjects, such as music (Robinson, 2017), and for educators at all levels, including prospective and practicing teachers, as well as teacher educators (Jett \& Cross, 2016; Murdock \& Hamel, 2016; Sharma et al., 2016). Speaking specifically about social class, Hunt and Seiver (2018) say:

It is important to provide appropriate teacher education and professional development that helps educators recognize and resist deficit views of economically disadvantaged students and families and to support teachers in identifying and changing elements of school culture and curriculum that may marginalize and pathologize class differences. (p. 353)

\subsection{Educational Development for Teaching Diverse Learners}

Student diversity, which includes differences based on social class background, is vital to address in teacher education (e.g., Tarozzi, 2014). However, focused attention to the topic is often limited to one educational foundations course (Milam et al., 2014). Experts agree that more attention should be given to teaching diverse learners and that this should occur across the curriculum in a teacher education program rather than in a single course (Jett \& Cross, 2016; Kumar \& Hamer, 2012; Murdock \& Hamel, 2016; Robinson 2017). Robinson (2017) notes, "One becomes culturally competen $[\mathrm{t}]$ over a period of time through a variety of experiences" (p. 23).

Amundsen and Wilson (2012) define educational development as "actions, planned and undertaken by faculty members themselves or by others working with faculty, aimed at enhancing teaching" (p. 90). Knowledge, skills, and dispositions are competency areas typically believed to be important within this development (e.g., Cummins \& Asempapa, 2013; DeVillar \& Jiang, 2012). An important precept for conducting effective educational development is creating an emotionally safe space in which to engage sensitive material openly and honestly (Jett \& Cross, 2016; Murdock \& Hamel, 2016; Pittaway, 2012). Within such a respectful environment, teachers should develop deep understanding of teaching and learning that involves theoretical and conceptual knowledge, as well as attention to belief systems (Ditchburn, 2015; Kumar \& Hamer, 2012; Tarozzi, 2014; Ünver, 2014). Tarozzi (2014) asserts that "a teacher's profile as a professional is embedded in inner beliefs, ideas, and world views" (p. 133) and that a "focus on concepts appears to be more enriching than a focus on practices" (p. 139). Foundational understandings, which include learning theoretical underpinnings of teaching 
methods and insights into student characteristics, are the basis for effective pragmatic approaches (Kumar \& Hamer, 2012; Ünver, 2014). For example, Kumar and Hamer's (2012) study with preservice teachers showed evidence of a link between prospective teachers' beliefs about student diversity and their projected instructional practices.

Critical reflection on one's own perspectives and on student characteristics, the nature of learning, and education practice is essential and can take place through carefully chosen readings and analytic writing that can stimulate and clarify thinking and through discussions that naturally embed feedback from peers (Ditchburn, 2015; Hunt \& Seiver, 2018; Jett \& Cross, 2016; Kumar \& Hamer, 2012; Murdock \& Hamel, 2016; Robinson, 2017; Ünver, 2014). Regarding social class, for example, Hunt and Seiver (2018) say educators should explore student differences based on family income and deficit perspectives that might associate with students from lower-class families. Other suggestions for helping educators develop a stronger foundation in teaching diverse learners are use of direct instruction that includes specific examples of culturally relevant practice at different grade levels (Murdock \& Hamel, 2016; Ünver, 2014), tasks involving critical evaluation of curricular materials for representation of diverse individuals and for perspectives portrayed (Hunt \& Seiver, 2018), direct experiences (e.g., field experiences) with a variety of students (Murdock \& Hamel, 2016; Sharma et al., 2016), and application of culturally competent understandings by developing action plans and lesson plans (Murdock \& Hamel, 2016; Ünver, 2014).

\subsection{Rationale for This Self-Exploration}

Research shows that professors' knowledge of content and pedagogy is highly important because "teacher candidates rely on the teaching competency of the instructors" (Ünver, 2014, p. 1405). Thus, those who educate teachers before and during practice need ongoing structured educational development themselves throughout their careers (Austin \& Sorcinelli, 2013; Cochrane, 2013). Faculty development in higher education is a burgeoning field (Amundsen \& Wilson, 2012). Like prospective and practicing teachers, teacher educators need various types of structured, facilitated activities to improve their practice. Some key areas of development include understanding oneself better as instructor (e.g., one's potential biases), strengthening content knowledge, and improving understanding of course design (Amundsen \& Wilson, 2012; Cochrane, 2013; Jett \& Cross, 2016) Like all professionals, teacher educators should have a safe environment to pursue faculty development through opportunities for reflection and for collaboration and discussion with peers, as well as readings and small-group activities (Amundsen \& Wilson, 2012; Austin \& Sorcinelli, 2013; Cochrane, 2013). Cochrane (2013) contends, "Building time and support for core reflection is critical for educators to connect with their deepest, authentic selves and for building connection from that self to students and subjects" (p. 33).

We thus set out as teacher educators to challenge and enhance our own perspectives and practice through self-examination and insights from student response to our instruction. We wanted to explore our own beliefs and attitudes and how our instructional approaches might help students understand the relationship of social class and education. Our decision to focus on social class was based on the fact that this was the course topic, one new to both of us, and that prospective and practicing teachers have been shown to possess stereotypic and constrictive perspectives toward students based on social class (Kumar \& Hamer, 2012; Stirrup et al., 2017), while teacher educators feel unprepared to teach this topic (Jett \& Cross, 2016). Despite the fact that "education... is subtly but profoundly classed" (Stirrup et al., 2017, p. 356), social class tends to be relegated to a backseat position among identity groups studied in teacher education (Glodjo, 2017; Hunt \& Seiver, 2018).

\subsection{Theoretical Framework}

This exploratory essay is couched in transformative learning theory, which posits that people hold assumptions that can be challenged by influential events or engaging activities (Christie, Carey, Robertson, \& Grainger, 2015; Mezirow, 1998). Nonthreatening discussions can encourage individuals to critically reflect on their own or others' viewpoints, thereby leading to altered perspectives and even attempted change (Brigham, 2011; Christie et al., 2015; Mezirow, 1998). Transformed thinking can, for example, result in efforts to create more favorable education or social practices (Carrington \& Selva, 2010; Christie et al., 2015). Transformative learning is thus inherently cognitive, affective, and social in nature (Brigham, 2011; Mezirow, 1998).

The theory of transformative learning specifically applies to adults and thus has implications for all forms of adult education (Christie et al., 2015; Mezirow, 1998). This theory is thus important to teacher education for its relevance to potential change in worldviews and practices. Brigham (2011) notes, "Adult learning theory, specifically transformative learning, yields a valuable theoretical framework for teachers and teacher educators" ( $p$ 51). Indeed, transformative learning theory is a useful lens for examining efforts to influence teacher learning (Brigham, 2011; Carrington \& Selva, 2010). 


\section{Context for This Paper}

As noted, one important area of development for educators at all levels is teaching diverse students. Within this area, an important factor is the role of students' social class. Accordingly, we wrote this paper as a reflective essay in our efforts to better understand how to teach students from different socioeconomic backgrounds. As two teacher educators (full professors) and four teacher education students (two graduate, two undergraduate), we had different reasons for seeking to improve our practice: facilitating teacher growth (teacher educators), improving P-12 practice (graduate students), and preparing for future teaching (undergraduate students).

The teacher educators created a course on social class and schooling, which was conducted in England as part of a study abroad program. A program expectation was to include course readings that focused on the host country in addition to other countries, most commonly the United States, where the course instructors and students resided. The course consisted of 15 class sessions of about two and one-half hours each spread across four and one-half weeks. Five classes were held online and the other ten in person. The main course topics included foundational concepts about social class; the relationship of social class to students' classroom and school experiences and to their academic performance; the intersection of social class with student identities based on exceptionality (students with disabilities and gifted/talented students), gender, and race/ethnicity; the role of family and community in relation to social class and schooling; teachers' perspectives and instructional practices; curricular and co-curricular areas; higher education; and recommended education strategies and resources. The only specific topics that spanned two class sessions were family and community, teachers' perspectives and instructional practices, and recommended education strategies. All others were addressed in one class session.

The six participants (two co-instructors and four students) serve as authors of this paper and all consented to include the data indicated below for use in preparing this paper. To critically reflect on our progress in understanding the relationship of social class to education, we drew from several structured writing sessions to write this essay. These data sources included individual writing during and after the course. This type of individual writing involving reflection on diversity in education followed by a look at bigger meanings across the writing is similar to that done by teacher educators in Jett and Cross (2016).

During the course, students responded to the following question posed on a written midterm exam and on the final exam: Name and explain two or three "big ideas" that have struck you most so far in this class (ones that have informed, interested, surprised, and/or troubled you). Describe how these have influenced you thus far academically and/or professionally. (The final exam noted that responses could repeat those written on the midterm exam.)

Seven months after the course ended, the six participants individually wrote responses to the following questions posed by email:

1) What are the most significant facts and/or ideas you remember learning or addressing during your summer course Social Class and Schooling? Please explain why you consider each significant.

2) What aspects of the course's instructional approach most influenced you to engage with and learn the course material?

3) In what ways could the course CONTENT and INSTRUCTIONAL APPROACH be improved to better inform and inspire you in relation to the topic of social class and schooling?

4) Describe any ways that the course influenced you in your personal, academic, and/or professional life since the course ended. Include examples. If the course did not influence you, please tell why you think it did not.

5) Add any other comments about the course that you would like to make.

Finally, another seven months later (14 months after the course ended), the six participants were asked why the role of parents was particularly salient in their previous written responses. All six individually explained their thinking in an email to the lead author.

The two instructors had the dual role of increasing their own learning about social class and schooling, as they considered themselves in early to intermediate stages of learning in this area, and conducting a class to help students do the same. Additionally, they answered the following questions intended to provide insight into instructor intent and efforts in relation to furthering student knowledge, skills, and dispositions on the role of social class in teaching and learning:

1) What are the main facts and ideas you wanted students to get from this course when you co-planned and co-taught it? Why?

2) What instructional approaches did you intentionally plan to try to get students to engage with and learn the 
course material more fully?

3) In what ways do you think the course content and instructional approach could have been improved to better inform and inspire students in relation to social class and schooling?

4) In what ways did you plan and teach the course in an effort to influence students' personal, academic, and/or professional life in relation to the course material?

5) Do you have other comments regarding your intent and efforts in planning and teaching the course to influence students, as educators, on the topic of social class and schooling?

The two teacher educators analyzed the written work and question responses into thematic categories by identifying ideas raised most often, a process that is not linear (Cresswell, 2014; Gay et al., 2012). These hand-coded categories were constructed during multiple readings of the data and were adjusted as needed until they were determined to represent the data accurately. This resulted in four main categories, detailed below. Prominent themes within categories helped to characterize overarching categories. For example, within the major category of most effective instructional approaches, two key themes were in-class discussions and varied instructional approaches. The categories were reviewed for their individual meaning and importance as well as for larger themes across categories in relation to the focus of this exploration. Finally, the four students reviewed the write-up to give feedback, which was incorporated into a paper revision, and again to provide agreement with the trustworthiness of the final text as presented.

\section{Course Influence on Understanding Social Class in Education}

In this section, we describe the themes we identified in our written comments across the three reflective writing points regarding how our course experience influenced the way we understand social class in teaching and learning. We identified four major categories in relation to the course content and pedagogy, as follows: salient content; most effective instructional approaches; application of course material; and suggested improvements. Each is described below.

\subsection{Salient Content}

When stating what we considered to be the most important course content, we as participants most often named foundational concepts and research-based findings regarding the role of social class in teaching and learning. Two of us (a graduate student and an instructor) noted the value of learning new terminology that would help us discuss relevant issues meaningfully and with a common language. This includes social class itself but also less commonly heard or understood terms: habitus, social capital, cultural capital, and the difference between socially just pedagogy and social justice pedagogy. One instructor wrote, "I developed a deeper understanding of social and cultural capital as well as habitus in the course as powerful explanatory tools for thinking about schooling and children's success in school." In general, we found the distinction between socially just pedagogy and social justice pedagogy important ("transforming" to the graduate student who wrote about these terms) but hard to wrap our heads around. At one point these terms sparked a long discussion between the two instructors outside of class that we ultimately decided would require further exploration to try to achieve adequate understanding and some degree of consensus.

Course content that struck us most tended to include deeper and more pivotal understandings. For example, two participants (an undergraduate student and an instructor) expressed more prominent awareness of how school culture values and privileges students of higher social classes and tends to tailor education to their linguistic and experiential background, thus affording them greater advantage (e.g., higher achievement) in education. A graduate student also considered the intersection of race/ethnicity with social class, for example, to be important in terms of how another factor might compound the effects of social class.

During the class we examined SES in relation to teaching and learning in general as well as to curricular and co-curricular areas (e.g., literacy resources, such as number of books at home, and opportunity to attend out-of-school-time mathematics and science programs). Four participants (an undergraduate student, a graduate student, and both instructors) commented on specific ways social class can influence the classroom experience and its outcomes. Some course material and reading indicated that students from low-SES families tend to get less exercise and be more overweight, as well as have fewer sporting opportunities than students from higher-SES families, and that choice of physical education activities can vary by social-class background (e.g., Optimal Performance Sports, 2009; Smith, Green, \& Thurston, 2009). Regarding the class-based sports participation divide, one instructor wrote, "I'm not sure why this stands out to me from last summer. It may be because it is really something I had not thought about much, so it was very different for me." A graduate student also expressed greater awareness of sports imbalances and why students from low-income backgrounds are 
scarce as sports participants.

Comparing SES issues in relation to education in our home country (the U.S.) and the host country for the course (the U.K.) was noteworthy to one graduate student and one instructor. The two found the similarities and differences important to recognize and noted that while education issues must be examined within the context of individual countries, both countries examined remain "divided along class, race, and gender lines" (graduate student) and that this information "reinforce[s] this issue as a transnational one" (instructor).

One of the most salient topics, raised by four participants (an undergraduate student, both graduate students, and one instructor), was the role of parents in terms of how social class can influence parents' ability to support their children's academics, as well as their relationship with schools in terms of their involvement and their access to information. One instructor found it unsettling that some parents can be marginalized even when they offer to participate in school volunteer work (cf. Levine-Rasky, 2009) and, likewise, a graduate student expressed concern "that so many times decisions are made regarding lower SES children and that parents are unaware or unsure of the impact of the decisions." These four also wrote that parent involvement and home practices can support students' education. Responses to the follow-up question regarding why the parental role was prominent in our earlier written comments include the influence parents can have on students' school success (five participants), the importance of parents as a potential educational resource to support student learning and performance (four participants), and concerns about inequities caused by SES-based power differentials among parents and between home and school (two participants). In explaining why they found the parent role so important as a course topic that influenced them, one stated, "Understanding the family's background may allow us to find a way to include parents in their child's education." Another connected the course material to her own life when she wrote that the family role is "a driving force for student academic success. I can personally attest to the impact my family's relationship with my teachers and members of my school(s) had on my academic success. It was profound." Still another expressed motivation to address the fact that "the balance of power lies in the hands of the teacher and the school, and parents enter meetings at a disadvantage as spectators and not team members."

Another theme regarding important course content was the key role of teachers in supporting the learning of all students, particularly those from underrepresented groups. Three participants (all students) described the importance of teachers holding high expectations for all students and being aware of their own personal lens. The written descriptions sometimes focused on the cognitive in the form of insights gained and at times the transformative in terms of increased awareness that participants anticipated would influence their future practice. Similarly, all four students found it important that the course included some practical application of the content. Examples include specific ideas for making the curriculum relevant to students (e.g., through service learning), using varied instructional approaches and assessments (such as a book club activity based on children's/young adult's books involving social class themes), and seeking and facilitating parent involvement.

\subsection{Most Effective Instructional Approaches}

In terms of which instructional approaches were perceived to have the greatest influence on engagement with the course material, in-class discussions appeared most prominently (five participants). Comments pointed to the value of the interactions themselves but also to the comfortable and open atmosphere in which discussion took place. Of course, having a small class size and a 1:2 teacher-to-student ratio contributed to this climate. Three participants each also considered the following important: the variety and arrangement of topics; the use of varied instructional approaches, some of which involved intentional planning and some of which occurred naturally due to instruction taking place by two instructors with different teaching styles. Both instructors wrote that working with a co-instructor in a safe setting furthered their knowledge, and one graduate student stated that having two instructors was important due to different presentation styles and greater student accountability. On this topic, one instructor (Wiest) wrote:

Another vitally important aspect was my co-instructor's willingness and active desire to forward her own learning and thinking. She invited me to tell her if I disagreed with her on any of her perspectives, which I did on at least two occasions.... In these cases, I tried to tell Cindy privately, but she asked that I tell the class. This degree of openness to opposing opinion was vital to my own degree of safety in pursuing sensitive course material more fully and openly, and it served as critically important modeling for the class.

Specific assignments were named fairly often as worthwhile instructional components. Two participants each named: in-class writing assignments in journals; the course readings; and student-generated discussion questions used in class. Finally, the two graduate students noted the value of studying abroad and spending time in an unfamiliar culture in general as an important "bonus" for extending the boundaries of one's cultural learning. 


\subsection{Application of Course Material}

Participants stated ways they believed they would apply the course material after the course had ended and, later, how actually implementing the course content was taking place. In terms of projected course influence, the types of awareness and understandings they developed (noted earlier) were prominent, including awareness of the role of social class in students' school performance, knowledge of key concepts such as social justice and cultural capital, and intent to hold high expectations for and support the academic success of all students. One undergraduate student said, "I will try to always make a conscious effort to push all students to succeed equally. I will not expect more or less from a student simply based on social class."

The importance and complexity of the role of parents was again prominent in comments that show the course material inspired reflection on what this means for teachers. One graduate student acknowledged:

It will be important for me to remember that many of the families I am working with have different "norms" or expectations and priorities in education. It may appear that parents at the school are not involved but it is important to remember that parents may feel involved, but have a different definition of parent involvement.

The other graduate student wrote:

In the revelations of the Baywoods vs. Kerrydale mothers [Levine-Rasky (2009) course reading], I considered whether or not my school is welcoming and inclusive to new moms. I considered practices that engender an "us vs. them" [quotation marks added for clarity] mentality such as PTA positions, room parent designations, office volunteers, etc. I was confronted with the uneasy suspicion that we in our own way had fostered similar sentiment and outcomes as those revealed by Levine-Rasky (2009)... [Parent involvement] of necessity means partnership with parents and practices that unite rather than divide.

The undergraduate students, too, were particularly struck by the topic of parent involvement in education and how it intersects with social class. One stated, "Above all, socio-economic status coupled with parent involvement resonated with me the most.... Ultimately, social class does not have to be a determinant of parent involvement." All three students who occupied a teaching position at a school during the fall that followed the summer course described ways they made changes in their practice to engage and support all parents to a greater degree. These proactive measures included creating afterschool homework help and holding parent information sessions.

Other ways the student participants perceived that the course influenced their education practice and/or subsequent academic work varied, such as engaging more intentionally with the curriculum, drawing on course readings and other content for specific purposes (e.g., to apply to other coursework), preparing all students for needed graphing calculator skills (i.e., not assuming they possessed a technological background), getting to know students better individually and seeking to meet their needs, and treating all students with respect and holding high expectations for them. One stated, "It is truly due to this course that I was able to understand my responsibility as an educator and the needs of my students prior to teaching them." Both instructors stated that they are trying to incorporate greater attention to social class and intersections among different dimensions of human diversity into their teacher education courses.

One graduate student and one instructor explicitly contended that the course inspired them to become advocates for individual students, especially those from low-income backgrounds, and to work toward influencing wider education practices. (Others implied this in intended actions they described for their future roles in schools.) Both described their intent to better support low-SES youth in everyday life and at school. The graduate student also noted that she had begun initiating change through frequent conversations with family, friends, and peers about "poor practices related to parent involvement, hot lunch stigmas, and classroom management in my school that had to be addressed.... The course was life changing for me, and I am sharing the information whenever the opportunity presents itself!"

\subsection{Suggested Improvements}

Three main suggestions appeared in our individual reflections about ways to improve the course to make it more effective in helping us, as educators, better understand the role of social class in teaching and learning. The one that appeared most often, suggested by five of the six of us, was to engage in more authentic experiences, specifically, to arrange guest speakers and/or visits to local classrooms. One undergraduate student stated that it would be useful to

allow us to gain knowledge and information about social class and justice from other sources, not just readings and the internet. For example, having an England native share their experience with us or taking us to a local school.... Also, partnering with an English professor...could add to the cultural experience for 
all of us and give us insight into the education system of the host country.

A graduate student suggested studying actual schools and talking to teachers to learn how they implement concepts and strategies because "it is still hard to conceptualize what social justice pedagogy might look like in a school or classroom." According to one instructor, these connections with local experts and contexts are important because "often we, as teachers, can't see past our own experiences."

A second recommendation for improving the course, offered by four participants (the two graduate students and two instructors), centered on devoting more time to course material so that it could be engaged in greater depth. Indeed, the course covered a large number of topics in relation to social class and thus took somewhat of a "survey-style" approach. Specific suggestions made beyond simple calls for more time with the course content were to include one class at the end of the course for digesting and applying the information, to have students conduct presentations on topics they individually chose and researched, and to write about and critique our own experiences. One instructor wrote, "Recognizing and critiquing our own experiences can help us to see issues (like social class) differently." The other instructor raised the topic of intersections among social identities as one that needed greater exploration in our course.

Whereas the second recommendation for improvement called for greater depth, the third proposed more breadth. Three of us suggested content (e.g., readings) drawn from a greater variety of schools and countries. One undergraduate student, for example, said she would like the course to include more attention to all social classes and how to support them in teaching and learning, not just students from lower/working-class backgrounds and schools.

\section{Closing Comments}

The two course instructors believe they met their goals for the students and themselves to gain greater knowledge of social class issues in schooling, practical methods for supporting students from different socioeconomic backgrounds, and enhanced dispositions toward serving the needs of students from, in particular, lower-income families and schools. As reported in extant literature (detailed earlier) and demonstrated in the data discussed in this paper, deeper knowledge and philosophical underpinnings of course content along with practical application of that content to teaching and learning are integral to educator growth and resulting changes in practice. The two teacher educators consider their own knowledge gains important precursors to planning and conducting educational development for prospective and practicing teachers.

We contend that the manner in which individuals develop targeted competencies in a course is highly dependent on the way learning experiences are designed and implemented. Effective instructional approaches encourage entry into and engagement with material, as well as development of appropriate dispositions that keenly tie to intentions and actions. In relation to the course discussed in this paper, the safe and honest environment for class discussions and co-instructors' discussions outside of class were integral to these efforts. So, too, was use of varied instructional approaches that required engagement with the material. Accordingly, one graduate student wrote:

Although there was much information to digest, the instructors were careful to use a variety of approaches for retention, including analytic essays, reflective writing, discussion question preparation, fact-finding, and exams. These resulted in a careful engagement with the course material which both informed and inspired.

Various other activities were also incorporated into class sessions, such as use of children's/young adult literature, a video, and a forced-choice activity. Another intentional course decision that the instructors consider important was holding students accountable for their reading by implementing graded reading responses at the beginning of each class. The two of us who served as course instructors maintain that this advance preparation and common ground for instructors and students enriched class discussions.

A challenging decision to make for this type of course is whether to teach it in greater breadth or in more depth. The former allows participants to address a wider number of topics more minimally but to include topics such as co-curricular areas (e.g., sports) that might not otherwise be pondered and which can then be pursued on one's own. The latter involves fewer topics but encourages deeper, more foundational learning. In any case, our foundational learning about the relationship of social class to education needs greater refinement by exploring intersections of other identities with social class, intra-class differences, and how social class manifests in different contexts (Glodjo, 2017; Hunt \& Seiver, 2018; Stirrup et al., 2017). Two additional areas of research that can help create a more nuanced look at social class in relation to education are studies of students from middle- and upper-class families, as well as students from lower-class families in suburban settings (Hunt \& Seiver, 2018).

We agree with the suggested course improvement that a greater number and variety of voices should be brought 
to the course material than that offered by the course instructors, the authors of required readings, and students enrolled in the course. Our collective observation that local guest speakers and field trips to schools would afford this are well founded for creating a richer, more authentic learning experience. This suggestion for including direct experiences in learning to work with diverse learners resonates with recommendations in the literature (Murdock \& Hamel, 2016; Sharma et al., 2016).

Kumar and Hamer (2012) emphasize a

need to examine how effectively teacher preparation programs empower preservice teachers to recognize their biases, overcome stereotype beliefs about less affluent and minority students, develop a sense of comfort in interacting with different others, and engage in classroom practices that reflect an openness to culturally diverse beliefs, values, and practices. (p. 163)

We believe our analytic reflections on the diversity-based teacher education course detailed in this paper contribute to this goal for both preservice and in-service teachers. Our efforts also involved pushing educational development even farther by seeking to advance the two course instructors' learning through structured individual writing and ongoing reflective discussions outside of class. Teacher educators who themselves engage in reflection on teaching have been shown to incorporate greater student reflection into their classes (Cochrane, 2013). We recognize that an opportunity to co-teach a course is rare, but teacher educators can build other communities with and connections to each other to serve similar purposes, which can help expand perspectives on and approaches to teaching (Austin \& Sorcinelli, 2013) and to help assuage the effects of teaching as "an isolating and highly pressured experience" (Cochrane, 2013, p. 32).

Our systematized reflective examinations of our own thinking and practice, specifically in relation to how social class influences education, yielded insights for all of us as educators at different levels, mainly based on gaining new understandings and ways to apply that learning to classroom practice. The mechanisms that drove this learning, namely, critical discussions in a safe setting teamed with impactful readings and reflective writing, support the tenets of transformative learning theory. We, however, suggest more nuanced consideration of the theory. In addition to the approaches just named, we contend that it is important to consider the needs of adult educators at different levels and that the role of direct experiences should figure more largely into the concept of transformative learning, as suggested by Murdock and Hamel (2016) and Sharma et al. (2016) and by two of the six authors in our individual reflections for improving methods aimed at promoting changed thinking and practice. While important at all levels, direct engagement with diverse individuals might be even more essential for younger and more novice educators, thus resonating with our recommendation that similar approaches across educator levels foster transformative learning, but their influence might be weighted or adapted differently among those levels. Learning communities, too, which are integral to transformative learning theory, might look different across educator levels. Cochrane (2013) states, "Faculty member needs and challenges often relate to the stage of one's teaching career, whether new, mid-career, or seasoned" (p. 32).

We contend that teacher educators should engage in a greater degree of faculty development because of the important role they play in educational development for both prospective and practicing teachers (e.g., Ünver, 2014). Their competency in how to teach diverse learners requires basic and applied knowledge, as well as appropriate dispositions. Like knowledge, dispositions can be learned (Cummins \& Asempapa, 2013).

Many areas "clamor" for attention in our efforts to push the teaching profession forward to greater effectiveness for all learners. Here, our focus was on our own development regarding the important role of social class in relation to teaching and learning (e.g., Hunt \& Seiver, 2018). As Christie et al. (2015) note, "If enough individuals within a field change, the field itself has a chance to change" (p. 22).

\section{References}

Amundsen, C., \& Wilson, M. (2012). Are we asking the right questions? A conceptual review of the educational development literature in higher education. Review of Educational Research, 82(1), 90-126. https://doi.org/10.3102/0034654312438409

Austin, A. E., \& Sorcinelli, M. D. (2013). The future of faculty development: Where are we going? New Directions for Teaching and Learning, n133, 85-97. https://doi.org/10.1002/t1.20048

Brigham, S. M. (2011). Braided stories and bricolaged symbols: Critical reflection and transformative learning theory for teachers. McGill Journal of Education, 46(1), 41-54. https://doi.org/10.7202/1005668ar

Carrington, S., \& Selva, G. (2010). Critical social theory and transformative learning: Evidence in pre-service teachers' service-learning reflection logs. Higher Education Research \& Development, 29(1), 45-57. https://doi.org/10.1080/07294360903421384 
Christie, M., Carey, M., Robertson, A., \& Grainger, P. (2015). Putting transformative learning theory into practice. Australian Journal of Adult Learning, 55(1), 9-30. Retrieved from https://files.eric.ed.gov/fulltext/EJ1059138.pdf

Cochrane, S. V. (2013). Courage in the academy: Sustaining the heart of college and university faculty. Journal of Faculty Development, 27(1), 28-34. Retrieved from https://www.couragerenewal.org/PDFs/Courage-in-the-Academy-SharleneCochrane.pdf

Cresswell, J. W. (2014). Research design: Qualitative, quantitative, and mixed methods approaches (4th ed.). Thousand Oaks, CA: SAGE.

Cummins, L., \& Asempapa, B. (2013). Fostering teacher candidate dispositions in teacher education programs. Journal of the Scholarship of Teaching and Learning, 13(3), 99-119. Retrieved from https://files.eric.ed.gov/fulltext/EJ1017120.pdf

DeVillar, R. A., \& Jiang, B. (2012). From student teaching abroad to teaching in the U.S. classroom: Effects of global experiences on local instructional practice. Teacher Education Quarterly, 39(3), 7-24.

Ditchburn, G. M. (2015). Remembering reflection in pre-service teachers' professional experience. Australian Journal of Teacher Education, 40(2), 94-111. https://doi.org/10.14221/ajte.2015v40n2.7

FairTest. (2013). College admissions test show test-driven schooling failure. Jamaica Plain, MA: National Center $\begin{array}{llllll}\text { for } & \text { Fair } & \& & \text { Open } & \text { Testing. } & \text { Retrieved }\end{array}$ http://www.fairtest.org/college-admissions-tests-show-testdriven-schooling

FairTest. (2015). SAT "college readiness" scores decline again demonstrating failure of test driven k-12 schooling; many more colleges ignore sat/act exam results as test-optional admissions movement surges. Jamaica Plain, MA: National Center for Fair \& Open Testing. Retrieved from http://www.fairtest.org/sites/default/files/2015-SAT-ScoresReaction.pdf

Gay, L. R., Mills, G. E., \& Airasian, P. (2012). Educational research: Competencies for analysis and applications (10th ed.). Boston: Pearson.

Glodjo, T. (2017). Deconstructing social class identity and teacher privilege in the second language classroom. TESOL Journal, 8(2), 342-366. https://doi.org/10.1002/tesj.273

Henderson, M., Sullivan, A., Anders, J., \& Moulton, V. (2018). Social class, gender and ethnic differences in subjects taken at age 14. The Curriculum Journal, 29(3), 298-318. https://doi.org/10.1080/09585176.2017.1406810

Hunt, C. S., \& Seiver, M. (2018). Social class matters: Class identities and discourses in educational contexts. Educational Review, 70(3), 342-357. https://doi.org/10.1080/00131911.2017.1316240

Jett, C. C., \& Cross, S. B. (2016). Teaching about diversity in black and white: Reflections and recommendations from two teacher educators. New Educator, 12(2), 131-146. https://doi.org/10.1080/1547688X.2015.1058448

Kumar, R., \& Hamer, L. (2012). Preservice teachers' attitudes and beliefs toward student diversity and proposed instructional practices: A sequential design study. Journal of Teacher Education, 64(2), 162-177. https://doi.org/10.1177/0022487112466899

Levine-Rasky, C. (2009). Dynamics of parent involvement at a multicultural school. British Journal of Sociology of Education, 30(3), 331-344. https://doi.org/10.1080/01425690902812604

Mahuteau, S., \& Mavromaras, K. (2014). An analysis of the impact of socio-economic disadvantage and school quality on the probability of school dropout. Education Economics, 22(4), 389-411. https://doi.org/10.1080/09645292.2014.918586

Martin, N. D. (2012). The privilege of ease: Social class and campus life at highly selective, private universities. Research in Higher Education, 53(4), 426-452. https://doi.org/10.1007/s11162-011-9234-3

Mezirow, J. (1998). On critical reflection. Adult Education Quarterly, 48(3), 185-198. https://doi.org/10.1177/074171369804800305

Milam, J. L., Jupp, J. C., Hoyt, M. W., Kaufman, M., Grumbein, M., O’Malley, M. P., \& ... Slattery, P. (2014). Autobiography, disclosure, and engaged pedagogy: Toward a practical discussion on teaching foundations in teacher education programs. Teacher Education and Practice, 27(1), 12-43.

Murdock, D., \& Hamel, E. (2016). I would quit my job: Unpacking preservice teachers' perceptions of culture 
and diversity. International Journal of Critical Pedagogy, 7(2), 85-106.

OECD. (2018). PISA 2015: Results in focus. Paris: Author. Retrieved from https://www.oecd.org/pisa/pisa-2015-results-in-focus.pdf

Optimal Performance Sports. (2009). Social class and its affects [sic] on sports. Retrieved from http://www.associatedcontent.com/article/1757062/social_class_and_its_affects_on_sports.html?cat=14

Pittaway, S. M. (2012). Student and staff engagement: Developing an engagement framework in a faculty of education. Australian Journal of Teacher Education, 37(4), 37-45. https://doi.org/10.14221/ajte.2012v37n4.8

Reardon, S. F. (2011). The widening academic achievement gap between the rich and the poor: New evidence and possible explanations. In G. J. Duncan \& R. J. Murnane (Eds.), Rising inequality, schools, and children's life chances (pp. 91-115). New York: Russell Sage Foundation.

Robinson, N. R. (2017). Developing a critical consciousness for diversity and equity among preservice music teachers. Journal of Music Teacher Education, 26(3), 11-26. https://doi.org/10.1177/1057083716643349

Sharma, S. A., Kasten, W. C., Smolen, L. A., Gupta, A., Kidd, J. K., Wright, T. S., \& Clifton, Y. (2016). Preparing culturally responsive teachers to meet the diverse needs in today's classroom: Phase one of a national study of literacy teacher educators. International Journal of Pedagogy \& Curriculum, 23(2), 59-74. https://doi.org/10.18848/2327-7963/CGP/v23i02/59-74

Smith, A., Green, K., \& Thurston, M. (2009). "Activity choice" and physical education in England and Wales. Sport, Education and Society, 14(2), 203-222. https://doi.org/10.1080/13573320902809096

Stirrup, J., Evans, J., \& Davies, B. (2017). Learning one's place and position through play: Social class and educational opportunity in early years education. International Journal of Early Years Education, 25(4), 343-360. https://doi.org/10.1080/09669760.2017.1329712

Stull, J. C. (2013). Family socioeconomic status, parent expectations, and a child's achievement. Research in Education, 90(1), 53-67. https://doi.org/10.7227/RIE.90.1.4

Tarozzi, M. (2014). Building an 'intercultural ethos' in teacher education. Intercultural Education, 25(2), 128-142. https://doi.org/10.1080/14675986.2014.888804

Ünver, G. (2014). Connecting theory and practice in teacher education: A case study. Educational Sciences: Theory \& Practice, 14(5), 1402-1407. https://doi.org/10.12738/estp.2014.4.2161

Wiederkehr, V., Darnon, C., Chazal, S., Guimond, S., \& Martinot, D. (2015). From social class to self-efficacy: Internalization of low social status pupils' school performance. Social Psychology of Education, 18(4), 769-784. https://doi.org/10.1007/s11218-015-9308-8

Zarifa, D., Kim, J., Seward, B., \& Walters, D. (2018). What's taking you so long? Examining the effects of social class on completing a bachelor's degree in four years. Sociology of Education, 91(4), 290-322. https://doi.org/10.1177/0038040718802258

\section{Copyrights}

Copyright for this article is retained by the author, with first publication rights granted to the journal.

This is an open-access article distributed under the terms and conditions of the Creative Commons Attribution license (http://creativecommons.org/licenses/by/4.0/). 